\title{
IMPACT OF COVID-19 PANDEMIC IN COUNTRIES AND SOME POLICY RECOMMENDATIONS FOR VIETNAM
}

\section{Dr. Hoai Nguyen Thi Thu}

University of Economics and Business

Vietnam National University

Email: hoaint04@yahoo.co.uk Vietnam

Dr. Lan Nguyen Thi Huong

University of Economics and Business

Vietnam National University

Email: lannth@vnu.edu.vn

Vietnam

\section{ABSTRACT}

The COVID-19 pandemic has been profoundly affecting economies in the region, but the severity and duration of the shock are extraordinary uncertainties. The policy response should focus on two immediate goals: Health protection measures and economic support for both supply and demand.

\section{KEYWORDS: COVID-19 and policy responses \\ 1. Introduction}

The COVID-19 pandemic has almost simultaneous impacts on all economies in the world but under different mechanisms both on the supply and demand sides. The degree of influence greatly depends on the structure of each economy as well as its link to the rest of the world. At the United Nations Conference on Trade and Development (UNCTAD) on March 9, experts warned that the new strain of coronavirus could cost the global economy about $\$ 1,000$ billion in losses this year. The global economy is likely to fall below $2.5 \%$, which is considered a threshold of recession for the world economy. The epidemic caused plummeting oil prices, increasing public debt, and companies could not stay at a time when they could not find customers or lack raw materials. According to the International Labor Organization (ILO), the UN agency, worldwide will lose 5-25 million jobs and will lose $\$ 860$ billion to $\$ 3.4$ trillion of labor income. "The global economy will go down. Some countries, like Italy and France, will fall into recession. Germany will also experience a technical recession. The right thing to do now is to spend more to avoid the worst-case scenario. We have learned from the economic crisis in 2008-2009, signaling that the world will witness a series of upcoming stimulus measures", said German economic analyst Robert Halver.

\section{Policy responses of some countries}

The COVID-19 pandemic has been profoundly affecting economies in the region, but the severity and duration of the shock are extraordinary uncertainties. This pandemic is unique in many ways, but there are still lessons we can learn from previous economic crises (such as the global financial crisis) and pandemics (for example flu. poultry and swine flu, SARS, MERS, Ebola virus disease (EVD), emphasizing the central role of employment, social protection and social dialogue in mitigation and recovery policies that countries Household application.

According to the latest World Bank report, growth in China under the baseline scenario is forecast to fall to $2.3 \%$ and under the lower-case scenario to $0.1 \%$ in 2020 , compared to $6,1 \%$ in 2019. Growth in other developing countries in the East Asia and Pacific region under the baseline scenario is forecast at $1.3 \%$ and the lower-case scenario is negative 2.8 $\%$ in 2020, compared with the estimated $4.7 \%$ in 2019. Restricting pandemic will be a condition for recovery, but the risk of prolonged financial stress is still large, even after 2020. Vulnerable. trade is the most dependent on trade, tourism, and trade; again, having large debts, and having to depend on volatile financial flows.

The COVID-19 shock will have a serious impact on poverty reduction, both directly through disease and indirectly through loss of income. According to the baseline World Bank forecast scenario, the number of people out of poverty in the region will decrease by 24 million in 2020 compared to the case without a pandemic (according to the poverty threshold of US \$ 5.50 / day). Under the lower-case scenario, the number of poor people is estimated to increase by about 11 million. Households related to the affected industries will be particularly difficult. For example, the poverty rate could double in Vietnamese households related to manufacturing and processing industries depending on imported inputs, as well as some Pacific island countries. There are jobs mainly dependent on tourism. Although estimates of GDP and poverty rates are only forecasts, they 


\section{International Journal of Business and Applied Social Science (IJBASS)}

E-ISSN: 2469-6501

VOL: 6, ISSUE: 4

April/2020

DOI: 10.33642/fjbass.v6n4p5

CPER

https://iibassnet.com/

\section{(C) Center for Promoting Education and Research (CPER) USA}

WWW.cpernet.org

show the extent of potential economic hardship and the need for urgent action.

Central banks in Australia, Canada, New Zealand, the United Kingdom, and the United States have cut interest rates. The Korean government has announced a special support package with a 20 trillion KRW budget in 2020. Italy has made tax and exemption deductions for social security contributions, as well as an extension of deadlines. mortgage repayment. Lending and financial assistance for specific areas, including the health sector. Financial support for specific areas has been published in many countries. In China, the government has set up a 300-billion-yuan credit facility to subsidize manufacturers of masks and other health-related items. In the UK, $£ 5$ billion has been allocated to the National Health Service (NHS), while in Ireland, the government has allocated 435 million euros to the Executive Medical Services. In Korea, tourism and other adversely affected industries have been identified to increase subsidies and longer support periods. France and Germany have announced a broad approach to support all affected areas. Germany announced unlimited support for businesses ${ }^{1}$. Measures to reduce wages during working/partial unemployment benefits, compensating workers for long hours without work, are expanding in France, Germany, Italy, and the Netherlands. In China, the government has issued a notice to ensure that migrant workers' contracts are not terminated in the event of illness or preventive measures. Unemployment benefits have been expanded in several countries. Inside the Philippines, the Social Security Program (SSS) is prepared to pay unemployment benefits for about 30,000 to 60,000 workers expected to lose their jobs after being laid off or shut down. Social assistance benefits or other forms of cash transfer are used in some countries to enhance income security and increase aggregate demand. In Hong Kong, China, adult residents will receive a one-time cash transfer of $\$ 1,280$, which is expected to boost the economy by $1 \%$.

Financial assistance and tax breaks are being introduced in some countries. The UK has introduced a guarantee system for $80 \%$ of the loan value for small and medium enterprises to lend and overdrawn and will provide an additional $£ 2.2$ billion to local governments to support businesses. small businesses. In South Korea, VAT reductions for businesses earning KRW 60 million or less a year and extended Special Financial Support for small and medium-sized businesses and businesses have been announced. In France, tax reductions allow all companies to delay "without justification, formally or penalize" payment of contributions and taxes due in March 2020. Affected companies Benefit can also benefit from deferring social tax payments or even reducing taxes to the most extreme or difficult circumstances. ${ }^{2}$

\section{Impact and recommendations of Vietnam's policy responses}

For Vietnam, the impact of the COVID 19 epidemic could leave the economy in a strong and long-term impact. The economy will decline rapidly due to a sharp decline in both total supplies (businesses decline production, broken input supplies ....) and total demand (domestic consumption demand and production investment decline. decreased, exports plummeted ...). Meanwhile, Vietnam is an economy with a great openness to the world, the foreign economic sector has been the locomotive for growth in recent years, so the impact of COVID 19 on the economy will be more recommended.

Only by the end of February 2020, the COVID-19 epidemic has had great consequences on the economic growth rate in Vietnam. According to the latest report of the Ministry of Planning and Investment to the Government, in the case of epidemic control in the first quarter of 2020, GDP growth in 2020 is forecast to be $6.25 \%$, down 0.55 percentage points compared to Resolution 01 / NQ-CP of the Government; in which, Q1 increased by $4.52 \%$; Quarter 2 increased by $6.08 \%$; third quarter increased by $6.92 \%$ and fourth quarter increased by $6.81 \%$. In case epidemic is controlled in Q2 / 2020, the growth is forecast to be $5.96 \%$, down by $0.84 \%$ compared to the Government's Resolution $01 /$ NQ-CP and down $0.29 \%$ compared to the restraint scenario was translated in Quarter 1/2020; in which, Q1 increased by $4.52 \%$; Quarter 2 increased by $5.1 \%$; Q3 increased by $6.70 \%$ and Q4 increased by $6.81 \%$. This information and the current situation of the epidemic are very much concerned by the Vietnamese business community and cannot be worried about the impacts of the disease and the negative impacts on all business activities. domestic trade and investment.

For Vietnam, it can be seen that Vietnam is the country most strongly and directly affected, both on the demand side and on the supply side. Accordingly, the BIDV Research and Education Institute has updated the Vietnam economic growth scenario in 2020 in the context of the COVID-19 pandemic (released on 10 April 2020), in which 3 growth scenario.

With the baseline scenario, the expert team of the BIDV Training and Research Institute said that the Government's measures in the prevention of epidemics as well as the policies to support the economy, businesses and people continue to develop. effectively, epidemics in 


\section{International Journal of Business and Applied Social Science (IJBASS)}

E-ISSN: 2469-6501

VOL: 6, ISSUE: 4

April/2020

DOI: 10.33642/fjbass.v6n4p5

CPER

\section{CCenter for Promoting Education and Research (CPER) USA}

WWW.cpernet.org

Vietnam were controlled in the second quarter of 2020 and economic and social activities soon returned to "normal" from June or early July 2020. According to this scenario, Vietnam's GDP growth in 2020 will decrease by 1.8 to 2 percentage points, equivalent to the growth rate of 4.81$5.01 \%$ (of which, the first quarter will achieve $3.82 \%$ growth. $\%$; Q2 is expected to increase by $3.45-3.67 \%$; for the first 6 months, it is forecast to increase by $3.81-4.05 \%)^{3}$.

With a positive scenario, countries around the world achieved positive results in disease prevention and control, measures of the blockade, and isolation without being prolonged (epidemic peaks in the US and Europe fell in late April to in the first half of May, after which the United States and Europe could control the epidemic in June 2020 and the COVID-19 pandemic was basically under control in the middle of the third quarter of 2020; production and business activities soon recovered from the end of the third quarter. In Vietnam, it is assumed that the outbreak of COVID-19 will be controlled in April 2020 or mid-May 2020; Production business activities were started shortly thereafter. Under this scenario, Vietnam's GDP growth in 2020 will decrease by 1.4 percentage points and reach $5.4-5.6 \%$.

With a negative scenario, outbreaks and pandemics were not controlled until the end of the third quarter, despite the efforts of governments of other countries. In Vietnam, the disease was controlled in the second quarter but was negatively affected by the total supply and demand from outside. Under this scenario, Vietnam's GDP growth will decrease by 2.58 percentage points to $4.07-4.42 \%$ by 2020 . The Vietnamese government responded quickly to the COVID-19 pandemic. A series of exemption and reduction policies and unprecedented relief packages have been introduced. The government has launched a VND 250 trillion credit package and VND 30 trillion support package. The State Bank of Vietnam (SBV) lowered the refinancing interest rate from $6.0 \%$ / year to $5.0 \%$ / year, the discount rate from $4.0 \%$ / year to $3.5 \%$ / year. The Ministry of Finance also proposed several economic instruments related to tax exemptions and reductions and fees. ${ }^{4}$

In times of crisis, policy responses should focus on two immediate goals: Health protection measures and economic support for both supply and demand. It can be said that the COVID-19 epidemic has a strong, even serious impact on the Vietnamese economy. Because of the multidimensional impact on all sectors of the economy, Vietnam's top priority now is to prevent COVID-19 from spreading. In the immediate future, limiting the spread of risk to humans as well as stamping out the epidemic is a top goal. But the difficult problem here is, how to save lives and epidemics at the same time, but can minimize the adverse effects on production, business, and economic development. Compared to the usual recession of an economy, COVID19 's economic impact is stronger and more disturbing.

The next policy measures to cope with crisis need to coordinate with countries, develop long-term scenarios, exercise cautious, controlled and uniform ways to create spillover, to avoid focusing only on, In particular, it is important to consider the continued use of bailout packages, which should focus on a group of policies and beneficiaries, and to promote economic activities to have a spillover effect.

Firstly, workers and their employers and their families need to be protected from COVID-19 health risks. Protection measures at workplaces and across communities should be introduced and strengthened, requiring large-scale public investment and support.

Secondly, timely coordinate policy efforts to provide employment and income support and to stimulate the economy and labor demand. These measures not only help businesses and workers against immediate job loss and income but also help prevent a series of supply shocks (such as loss of worker productivity) and Demand shocks (such as a reduction in consumption between workers and their families) can lead to the prolonged economic recession. Positive measures on a large scale and implementation in all policy areas are needed to create strong and sustained impacts. As the crisis is growing rapidly, careful monitoring of the direct and indirect impacts of all interventions is important to ensure relevant and sustained policy responses.

Third, accurate, consistent, timely and transparent information is essential not only to combat pandemics but also to reduce uncertainty and enhance confidence at all levels of the economy. and society, including the workplace. The decline or lack of confidence affects consumer spending and business investment, causing economic recession and hindering recovery.

Fourth, building trust through trust and dialogue is important in making effective policy measures. The government is unable to address the causes and consequences of the crisis and does not guarantee social stability and recovery through unilateral action. Social dialogue is an irreplaceable tool for crisis management and accelerating recovery as well as an essential governance tool for change. Especially during periods of increased social stress and lack of trust in organizations, increased respect for and reliance on social dialogue mechanisms to create a strong basis for building user commitments. workers and workers in joint action with the government. The constructive and persistent social dialogue between the 
government and social partners plays an important role in developing effective responses at the enterprise, sectoral and macroeconomic levels. Confirmed communication channels and continued dialogue with the government are key to enabling workers and employers to organize sustainable corporate governance and job retention.

\section{Conclusion}

The COVID-19 epidemic has been and continues to be a major threat to society in both global. The danger of the
SARS-CoV-2 virus strain makes the world in turmoil. In the prevention and control of COVID-19; government response and administration; with the same attitude and bravery of each citizen will decide the success or failure. When the spiritual "resistance" of each individual, the determination of the people and the government go together to overcome difficulties, spread human values, foster loving-kindness, the disease will surely be pushed. Back, the economy will gradually recover and grow.

\section{REFERENCES}

1. BIDV Training and Research Institute, Updated report on Vietnam's economic growth scenario 2020

2. "In a war, we draw”: Vietnam's artistsjoin fight against COVID-19 The Guardian.

3. How Vietnam is wining it's 'war' on coronavirus. DW ( 26 March,2020)

4. Vietnam shows how you can contain COVID-19 with limited resources. Weforum.org (30, March, 2020).

5. World Bank, Assess the impact of COVID-19 on economic growth.

6. https://www.worldbank.org/vi/news/press-release/2020/01/08/modest

7. http://vneconomy.vn/wb-tang-truong-kinh-te-toan-cau-2020-tang-nhe-nhung

8. Ilo.org/global/topics/coronavirus

9. http://baochinhphu.vn/Kinh-te/ 